\title{
THE
}

\section{Eugenia jambolana Lam. Berry Extract Inhibits Growth and Induces Apoptosis of Human Breast Cancer but Not Non- Tumorigenic Breast Cells}

Liya Li

Lynn S. Adams

Shiuan Chen

Caroline Killian

Aftab Ahmed

University of Rhode Island

See next page for additional authors

Follow this and additional works at: https://digitalcommons.uri.edu/bps_facpubs

This is a pre-publication author manuscript of the final, published article.

Terms of Use

All rights reserved under copyright.

\section{Citation/Publisher Attribution}

Li, L., Adams, L. S., Chen, S., Killian, C., Ahmed, A., \& Seeram, N. P. (2009). Eugenia jambolana Lam. Berry Extract Inhibits Growth and Induces Apoptosis of Human Breast Cancer but Not Non-Tumorigenic Breast Cells. J. Agric. Food Chem., 57(3), 826-831. doi: 10.1021/jf803407q

Available at: https://doi.org/10.1021/jf803407q

This Article is brought to you for free and open access by the Biomedical and Pharmaceutical Sciences at DigitalCommons@URI. It has been accepted for inclusion in Biomedical and Pharmaceutical Sciences Faculty Publications by an authorized administrator of DigitalCommons@URI. For more information, please contact digitalcommons-group@uri.edu. 


\section{Authors}

Liya Li, Lynn S. Adams, Shiuan Chen, Caroline Killian, Aftab Ahmed, and Navindra P. Seeram

This article is available at DigitalCommons@URI: https://digitalcommons.uri.edu/bps_facpubs/159 


\title{
Eugenia jambolana Lam. Berry Extract Inhibits Growth and Induces Apoptosis of Human Breast Cancer but not Non- Tumorigenic Breast Cells
}

\author{
Liya Li $§, \Phi$, Lynn S. Adams ${ }^{\dagger}, \Phi$, Shiuan Chen ${ }^{\dagger}$, Caroline Killian§, Aftab Ahmed $§$, and Navindra \\ P. Seeram $\$$, \\ $\S$ Bioactive Botanical Research Laboratory, Department of Biomedical and Pharmaceutical Sciences, College \\ of Pharmacy, University of Rhode Island, Kingston, RI \\ $\dagger$ Department of Surgical Research, Beckman Research Institute of the City of Hope, Duarte, CA
}

\begin{abstract}
The ripe purple berries of the native Indian plant, Eugenia jambolana Lam., known as Jamun, are popularly consumed and available in the United States in Florida and Hawaii. Despite the growing body of data on the chemopreventive potential of edible berry extracts, there is paucity of such data for Jamun fruit. Therefore our laboratory initiated the current study with the following objectives:1) to prepare a standardized Jamun fruit extract (JFE) for biological studies and, 2) to investigate the anti-proliferative and pro-apoptotic effects of JFE in estrogen dependent/aromatase positive (MCF-7aro), and estrogen independent (MDA-MB-231) breast cancer cells, and in a normal/nontumorigenic (MCF-10A) breast cell line. JFE was standardized to anthocyanin content using the $\mathrm{pH}$ differential method, and individual anthocyanins were identified by high performance liquid chromatography with ultraviolet (HPLC-UV) and tandem mass spectrometry (LC-MS/MS) methods. JFE contained 3.5\% anthocyanins (as cyanidin-3-glucoside equivalents) which occur as diglucosides of five anthocyanidins/aglycons: delphinidin, cyanidin, petunidin, peonidin and malvidin. In the proliferation assay, JFE was most effective against MCF-7aro $\left(\mathrm{IC}_{50}=27 \mu \mathrm{g} / \mathrm{mL}\right)$, followed by MDAMB-231 $\left(\mathrm{IC}_{50}=40 \mu \mathrm{g} / \mathrm{mL}\right)$ breast cancer cells. Importantly, JFE exhibited only mild antiproliferative effects against the normal MCF-10A ( $\mathrm{IC}_{50}>100 \mu \mathrm{g} / \mathrm{mL}$ ) breast cells. Similarly, JFE (at $200 \mu \mathrm{g} / \mathrm{mL}$ ) exhibited pro-apoptotic effects against the MCF-7aro ( $\mathrm{p} \leq 0.05)$ and the MDA-MB-231 ( $\mathrm{p} \leq 0.01)$ breast cancer cells, but not towards the normal MCF-10A breast cells. These studies suggest that JFE may have potential beneficial effects against breast cancer.
\end{abstract}

\section{Keywords}

Eugenia jambolana; Jamun berries; anthocyanins; antiproliferative; apoptosis; breast cancer

\section{INTRODUCTION}

Breast cancer is a leading cause of cancer-related deaths in the United States and is estimated to kill more than 400,000 women and 400 men for the year 2007 alone (1). In fact, breast cancer accounts for more than 1 in 4 cancers diagnosed in women in the United States. Reproductive hormones, such as estrogen, are thought to influence breast cancer risk through effects on cell proliferation and DNA damage as well as promotion of cancer growth. Early menarche $(<12$

\footnotetext{
*Author to whom correspondence should be addressed; Phone/Fax: 401-874-9367/5787 Email:E-mail: nseeram@mail.uri.edu.

$\Phi_{\text {These authors contributed equally towards this study }}$
} 
years), older age at menopause ( $>55$ years), older age at first full-term pregnancy ( $>30$ years), and fewer number of pregnancies may increase a woman's risk of breast cancer by affecting the levels of reproductive hormones produced by her body (1).

Although pharmaceutical agents have a therapeutic role in breast cancer, there is emerging evidence on the preventive role of plant extracts including dietary agents. For example, previous studies have shown that white button mushrooms (Agaricus bisporous) exhibit breast cancer chemopreventive ability through suppression of aromatase, the enzyme responsible for estrogen synthesis (2). Other foods, such as pomegranate (Punica granatum), have also been shown to be effective against breast cancer through the inhibition of aromatase activity (3). Because a large percentage of both pre- and post-menopausal patients have estrogen-dependent carcinomas, the suppression of estrogen formation by using dietary agents capable of acting as aromatase inhibitors, may offer a useful prevention strategy in these high risk individuals.

The native Indian tree, Eugenia jambolana Lam. (syn. Syzygium cuminii Skeels; Eugenia cuminii Druce.; Family: Myrtaceae), is found widely in the Asian sub-continent and other tropical regions of the world including South America and Madagascar. In the United States, E. jambolana is found in Florida and Hawaii (USDA Natural Resource Conservation Service Plant Database). When ripened, the edible fruits of E. jambolana, known as Jamun or Jambul (in India), Jambolão (in Brazil), and Java plum (in the United States), are deep purple oblong berries similar in appearance to a purple grape but with a large centrally located pit (picture shown in Figure 1). The pulp of the Jamun berry contains the anthocyanins, delphinidin, petunidin and malvidin-diglucosides, which impart its bright purple color $(4,5)$. Both the fruit pulp and seed extracts of the Jamun berry have a long history of medicinal use and they have been extensively studied for their anti-diabetic properties (recently reviewed in 6). Despite a growing body of evidence supporting the anticancer properties of anthocyanin-rich berry extracts (reviewed in 7), there is paucity of data on Jamun berries. Therefore our laboratory initiated the current study with the following objectives: 1 ) to prepare a standardized Jamun fruit extract (JFE), enriched in anthocyanins, for biological studies and, 2) to investigate JFE for in vitro anti-proliferative and pro-apoptotic effects in breast cancer (MCF7aro and MDAMB-231) and normal breast (MCF10A) cells. The MCF-7aro breast cancer cells are estrogen receptor (ER) positive/aromatase positive cells and the MDA-MB-231 are triple negative [lacking expression of ER, PR (progesterone receptor) and human epidermal growth factor receptor 2 (HER-2)].

\section{MATERIALS AND METHODS}

\section{Reagents}

All solvents were either analar or HPLC grade and purchased Wilkem Scientific Co. (Pawtucket, RI). The XAD-16 resin (Amberlite) was obtained from Sigma-Aldrich (Saint Louis, MO).

\section{Preparation of Jamun Fruit Extract (JFE)}

Freeze-dried Jamun pulp powder (500 g) obtained from fruits collected in Gujarat, India was kindly provided by Verdure Sciences (Noblesville, IN). The identification of Eugenia jambolana Lam. (syn. Syzigium cumini L. Skeels) fruit was authenticated by matching the macroscopic and microscopic characteristics of the plant parts to internal monograph and botanical reference standards and botanically authenticated specimens have been deposited at Verdure Sciences. The Jamun fruit extract was enriched in anthocyanins and prepared according to previously published methods with slight modifications $(8,9)$. Briefly, a portion of the freeze-dried whole fruit powder $(260 \mathrm{~g})$ was sequentially and exhaustively extracted with cold hexanes, followed by ethyl acetate, then acidified methanol ( $0.1 \%$ hydrochloric acid). 
The solvents were removed in vacuo using a rotary evaporator, with water bath temperature at $35^{\circ} \mathrm{C}$, to yield dried hexanes $(1.1 \mathrm{~g}$; pale green color), ethyl acetate $(2.0 \mathrm{~g}$; green-brown color) and methanol (100.0 g; dark red-purple color) extracts. Based on a combination of visual appearance for red-purple coloration (indicating the presence of anthocyanins), and HPLC analysis by monitoring at $530 \mathrm{~nm}$ (the characteristic absorbing wavelength of anthocyanins), the methanol extract was selected for further purification. The extract $(100.0 \mathrm{~g})$ was reconstituted in water and enriched in anthocyanin content by using adsorption chromatography on an XAD-16 Amberlite resin column. The extract was adsorbed onto the resin and eluted with water $(5 \mathrm{~L})$ to remove sugars and acids that are naturally found in the fruit. The column was then eluted with acidic methanol ( $0.1 \%$ hydrochloric acid) to afford a red-purple Jamun fruit extract (JFE, $16.0 \mathrm{~g}$ ) after solvent removal as described above.

\section{Anthocyanin Content of JFE}

The anthocyanin content was determined by using the $\mathrm{pH}$ differential method and was calculated as equivalents of cyanidin-3-glucoside, using the extinction coefficient of $26900 \mathrm{~L}$ $\mathrm{cm}^{-1} \mathrm{mg}^{-1}$ and a molecular mass of $449.2 \mathrm{~g} / \mathrm{L}$ as previously reported (10). Briefly, an accurately weighed sample of the extract was used to make a stock solution in a $100 \mathrm{~mL}$ volumetric flask. Two aliquots of this stock solution $(1.0 \mathrm{~mL}$ each) were removed and placed into separate $25 \mathrm{~mL}$ volumetric flasks which where made up to mark with pre-prepared buffers of $\mathrm{pH} 1.0$ or $\mathrm{pH} 4.5$, respectively. Absorbance of these two buffer solutions were recorded at $510 \mathrm{~nm}$ using a spectrophotometer (Spectramax M2, Molecular Devices, operated by SoftmaxPro v.4.6 software). According to this assay protocol, absorbance can also be recorded at $700 \mathrm{~nm}$ if there is sample turbidity. The difference in absorbance between the two samples is then calculated using the formula: Absorbance $=\left(\mathrm{A}_{510 \mathrm{~nm}} \mathrm{pH} 1.0-\mathrm{A}_{700 \mathrm{~nm}} \mathrm{pH} 1.0\right)-$ $\left(\mathrm{A}_{510 \mathrm{~nm}} \mathrm{pH} 4.5-\mathrm{A}_{700 \mathrm{~nm}} \mathrm{pH} 4.5\right)$. Finally the $\% \mathrm{w} / \mathrm{w}$ of total anthocyanins in the sample is calculated by using the formula: $\% \mathrm{w} / \mathrm{w}$ Anthocyanins $=A / \varepsilon \mathrm{L} \times \mathrm{MW} \times \mathrm{DF} \times \mathrm{V} / \mathrm{Wt} \times 100 \%$ where $\mathrm{A}=$ Absorbance; $\varepsilon=$ cyanidin-3-glucoside molar absorbance $(26,900)$; $\mathrm{MW}=$ anthocyanin molecular weight $(449.2 \mathrm{~g} / \mathrm{L}) ; \mathrm{DF}=$ dilution factor; $\mathrm{V}=$ final volume $(\mathrm{mL}) ; \mathrm{Wt}$ $=$ sample weight $(\mathrm{mg}) ; \mathrm{L}=$ cell path length $(1 \mathrm{~cm})$. JFE contained $3.6 \%$ anthocyanins as cyanidin-3-glucoside equivalents.

\section{High Performance Liquid Chromatography (HPLC-UV)}

All HPLC analyses were conducted on a Shimadzu LC-10AS pump with a photodiode array (PDA)-UV-VIS detector and operated by Class VP version 4.2 software. All samples ( $20 \mu \mathrm{L}$ injection volume; $10 \mathrm{mg} / \mathrm{mL}$ concentrations) were filtered $(0.22 \mu \mathrm{M})$ and analyzed on a Luna C-18 column (Phenomenex; $250 \times 4.6 \mathrm{~mm}$ i.d., $5 \mu$ ). The mobile phase, solvent A: $3.5 \%$ aqueous phosphoric acid, and solvent B: acetonitrile; Gradient \%A: intial: 95\%, 10 min: 90\%, 20 min: 87\%, 30 min: 82\%, $35 \mathrm{~min}: 75 \%$, $40 \mathrm{~min}: 40 \%$, $41 \mathrm{~min}$ : 95\%; run time $61 \mathrm{~min}$; flow rate 0.75 $\mathrm{mL} / \mathrm{min}$; anthocyanins were monitored at $530 \mathrm{~nm}$.

\section{Liquid Chromatography Mass Spectrometry (LC-MS)}

All LC-MS analyses were carried out on a Q-Star Elite (Applied Biosystems MDS) time of flight (TOF) mass spectrometer equipped with a Turbo Ionspray source and coupled to an HP 1100 series HPLC system consisting of an autosampler/injector, quaternary pump, and diode array (DAD) detector. Data handling was carried out using Analyst QS version 2.0 software (Applied Biosystems). Conditions for detection of anthocyanins were as follows: Column: XBridge C18, $100 \mathrm{~mm} \times 4.5$ i.d., $5 \mu \mathrm{m}$, (Waters Corp., Milford, MA); Solvent A: $1 \%$ aqueous formic acid; solvent B:1\% formic acid in methanol ; Gradient \% A: intial: 95\%, 5 min: 95\%, 15 min: 90\%, $60 \mathrm{~min}: 80 \%$, $65 \mathrm{~min}: 80 \%, 67 \mathrm{~min}: 95 \%, 80 \mathrm{~min}$ : 95\%; run time: $80 \mathrm{~min}$; flow rate: $0.15 \mathrm{~mL} / \mathrm{min}$; injection volume: $20 \mu \mathrm{L}$; column temperature: $30^{\circ} \mathrm{C}$; DAD range: $210-600$ $\mathrm{nm}, 530$ as detection wavelength for anthocyanins. MS parameters: Ionization mode ESI+; 
scan range: $400-1000 \mathrm{amu}$; scan rate: $1 \mathrm{scan} / \mathrm{sec}$. Peak identities were obtained by matching their molecular $\mathrm{M}^{+}$and MS/MS ions as shown in Table 1 and Figure 2 and by comparison to literature data $(11,12)$.

\section{Cell Culture Materials}

The breast cell lines, MCF-7, MDA-MB-231 and MCF10, were obtained from the American Type Culture Collection (ATCC) (Rockville, MD). The MCF-7aro cells were prepared from MCF-7 by transfection with human CYP19 (MCF-7aro) as previously reported (2). The different cell lines were cultured in their ATCC recommended media as follows. The MCF-7 cells were cultured in Eagle's minimum essential medium (MEM) (Invitrogen, Grand Island, NY) supplemented with $10 \%$ fetal bovine serum (FBS) and the antibiotic G418 $(500 \mu \mathrm{g} / \mathrm{mL})$ (UBS Corporation, Cleveland, OH). MCF-7aro cells were cultured in Eagle's MEM with Earle's salts, $1 \mathrm{mmol} / \mathrm{L}$ pyruvate, $2 \mathrm{mmol} / \mathrm{L}$ glutamine (Irvine Scientific, Santa Ana, CA), and $10 \%$ heat-inactivated FCS ( $\triangle$ FCS; Omega Scientific, Tarzana, CA). MCF-10A cells were cultured in 50:50 DMEM/HAM's F-12 supplemented with 10\% horse serum, $2 \mu \mathrm{mol} / \mathrm{L}$ insulin, $0.5 \mathrm{mg} / \mathrm{L}$ hydrocortisone, $20 \mu \mathrm{g} / \mathrm{L}$ epidermal growth factor, and $100 \mu \mathrm{g} / \mathrm{L}$ cholera toxin. MDAMB-231 cells were cultured in RPMI-1640 supplemented with $10 \% \Delta$ FCS. All cell lines were incubated in a humidified environment at $37^{\circ} \mathrm{C}$ in $5 \% \mathrm{CO}_{2}$ and maintained in the linear phase of growth.

\section{Cell Proliferation Assay}

Proliferation was measured utilizing the CellTiter-Glo® Luminescent Cell Viability Assay (Technical Bulletin \# 288, Promega Corp., Madison, WI) as previously reported (13). When added to cells, the assay reagent produces luminescence in the presence of ATP from viable cells. Briefly, cells were plated in 96-well plates at a density of 5,000 cells/well and incubated for 24 hours. Test samples were solubilized in DMSO by sonication, filter sterilized, diluted with media to the desired treatment concentration and immediately used in the experiment. The final DMSO concentration per well did not exceed $0.3 \%$. Cells were treated with $100 \mu \mathrm{L}$ media or test samples and incubated for 24,48 or $72 \mathrm{~h}$ sample exposure duration. JFE was tested at $0,12.5,25,50$, and $100 \mu \mathrm{g} / \mathrm{mL}$ concentrations. At the end of the 24,48 or $72 \mathrm{~h}$ sample exposure duration, plates were equilibrated at room temperature for $30 \mathrm{~min}, 100 \mu \mathrm{L}$ of the assay reagent was added to each well and cell-lysis was induced on an orbital shaker for $2 \mathrm{~min}$. Plates were then incubated at room temperature for $10 \mathrm{~min}$ to stabilize the luminescence signal and results were read on an Orion Microplate Luminometer (Bertholds Detection Systems, Pforzheim, Germany). All plates had control wells containing medium without cells to obtain a value for background luminescence which was subtracted from the test sample readings. Three separate experiments were conducted and data are expressed as a ratio of treated to untreated cells, mean $\pm \mathrm{SE}$ for three replications.

\section{Assessment of Apoptosis}

Apoptosis was assessed utilizing the Cell Death Detection ELISA ${ }^{\text {PLUS }}$ Assay (Boehringer Mannheim, Indianapolis, IN) as previously reported (13). This assay is a photometric enzymelinked immunoassay that quantitatively measures the internucleosomal degradation of DNA, which occurs during apoptosis. Specifically, the assay detects histone associated mono- and oligonucleosomes, which are indicators of apoptosis. Briefly, cells were plated in $60 \mathrm{~mm}$ dishes at a density of 250,000 cells/dish and allowed to attach for $24 \mathrm{~h}$. Cells were then treated with media control or JFE at 100 or $200 \mu \mathrm{g} / \mathrm{mL}$ concentrations for $48 \mathrm{~h}$. Following treatments, nonadherent cells were collected and pelleted at $200 \times \mathrm{g}$ for ten minutes. The supernatant was discarded and the cell pellet was washed with cold CMF-PBS and re-centrifuged. Adherent cells were washed with cold calcium magnesium free-phosphate buffered saline (CMF-PBS, $137 \mathrm{mmol} / \mathrm{L}$ sodium chloride, $1.5 \mathrm{mmol} / \mathrm{L}$ potassium phosphate, $7.2 \mathrm{mmol} / \mathrm{L}$ sodium 
phosphate, $2.7 \mathrm{mmol} / \mathrm{L}$ potassium chloride, $\mathrm{pH}$ 7.4), trypsinized, collected and combined with non-adherent cells into a total of $1 \mathrm{~mL}$ DMEM. Both live and dead cells were then counted via trypan blue exclusion (Pierce, Rockford, IL), equal numbers of cells were added to the microtiter plate for all treatment groups, and the apoptosis assay was performed according to the manufacturer's instructions. Data are expressed as absorbance at $405 \mathrm{~nm}$ of each sample over vehicle controls.

\section{Statistical Analysis}

Data were analyzed by either student's t-test, one-way ANOVA followed by Dunnett's Multiple Range test $(\alpha=0.05)$ or two-way ANOVA with Graph Pad Prism 3.0 (Graph Pad Software Inc.) as appropriate.

\section{RESULTS AND DISCUSSION}

\section{Phytochemical Studies on Jamun Fruit Extract (JFE)}

Although JFE may contain a wide diversity of phytochemical constituents, in the current study, JFE was standardized to anthocyanin content (3.5\% anthocyanins, as cyanidin-3-glucoside equivalents) using the $\mathrm{pH}$ differential method. Anthocyanin-rich extracts are frequently standardized to cyanidin-3-glucoside equivalents by both research $(10,14)$ and industrial laboratories (see NSF, an independent non-profit third-party certification provider: www.nsf.org). This is because of the historical usage of cyanidin-3-glucoside for similar assays and its wide commercial availability. The use of a common accepted standard to quote anthocyanin content is pertinent, considering that many fruits, vegetables and derived food products contain a mixture of several anthocyanins (12).

Five anthocyanins were detected in JFE by using HPLC-UV analyses and their relative proportions in order of increasing HPLC retention times $\left(t_{R}\right)$ were peak $3\left(t_{R} 27.2 \mathrm{~min}\right)>$ peak $5\left(t_{R} 31.9 \mathrm{~min}\right)>$ peak $1\left(t_{R} 22.4 \mathrm{~min}\right)>$ peak $2\left(t_{R} 25.4 \mathrm{~min}\right)>$ peak $4\left(t_{R} 30.7 \mathrm{~min}\right)($ see Figure $2 \mathrm{~A})$. The anthocyanins were then identified by LC-MS/MS analyses from the mass/charge $(\mathrm{m} /$ z) ratios of their molecular ions $\left(\mathrm{M}^{+}\right)$and of their MS/MS product ions as follows: peak $1=$ delphinidin-diglucoside $(627 ; 465 / 303)$; peak $2=$ cyanidin-diglucoside $(611 ; 449 / 287)$; peak $3=$ petunidin-diglucoside $(641 ; 479 / 317)$, peak $4=$ peonidin-diglucoside $(625 ; 463 / 301)$, and peak $5=$ malvidin-diglucoside $(655 ; 493 / 331)$ (see Figure 2B and Table 1). This is in agreement with a previous report for E. jambolana fruits collected in Brazil (11). In that study, of several tropical fruits analyzed for anthocyanin content, Jamun berries displayed the widest variability in aglycone structure (11). Anthocyanins from fruits typically display patterns of either having different aglycones present with matching sugar patterns, as in the case of Jamun berries, or a single dominant aglycone with other minor anthocyanin components present (12).

There is disagreement in the literature about the point(s) of attachment for the dissacharose units of anthocyanins from $E$. jambolana fruit as being either on the 3 and 5 positions (i.e. as 3,5-diglucosides), as reported by de Brito et al (11), or on the 3-postion alone (as gentiobiose and laminaribiose), as reported by Jain and Seshadri (15). It should be noted that without authentic anthocyanin standards, whose structures have been unequivocally identified by proton and/or carbon-13 nuclear magnetic resonance $\left({ }^{1} \mathrm{H}\right.$ and $\left.{ }^{13} \mathrm{C}-\mathrm{NMR}\right)$ spectrometry, the utilization of HPLC-UV and LC-MS/MS techniques cannot determine the points of attachment of the disaccharide units to anthocyanidin/aglycon unit. To this end, our laboratory is currently pursuing the isolation and structural elucidation (using NMR methods) of the individual anthocyanins present in the JFE used in our study. In addition, further studies to identify other phytochemical constituents (non-anthocyanin phenolics and non-phenolics) present in JFE, which may contribute towards its observed biological activities, are necessary. 
There are also differences reported for anthocyanin profiles in E. jambolana fruits collected from different geographical regions. For example, the fruits used in the current study had a similar 'five anthocyanin profile' to those collected in Brazil (11), but are different from those collected in Egypt (16). In that study, fruits collected from Egypt had a 'four anthocyanin profile' consisting of pelargonidin-3-glucoside, pelargonidin-3,5-diglucoside, cyanidin-3malonyl-glucoside and delphinidin-3-glucoside (16). It is not unusual for fruits collected from different geographical locations to have different phytochemical profiles. Indeed, the anthocyanidins present in the Jamun berries in our study were in the order of relative proportion of petunidin>malvidin>delphinidn>cyanidin>peonidin while the Brazilian berries had delphinidin $>$ petunidin $>$ malvidin $>$ cyanidin $>$ peonidin (11). This highlights the importance of utilizing well-characterized and standardized materials for biological studies since their bioactivities may differ tremendously based on their phytochemical profile and individual constituents. Future studies to identify the anthocyanins present in $E$. jamoblana fruits collected from different countries are currently being pursued in our laboratory.

\section{Antiproliferative Effects of Jamun Fruit Extract (JFE)}

JFE was tested against all cell lines at concentrations ranging from $0-100 \mu \mathrm{g} / \mathrm{mL}$ at three different time points of 24, 48 and $72 \mathrm{~h}$. The anti-proliferative bioassay showed that JFE significantly inhibited the growth of both the MCF-7aro (Fig. 3B) and MDA-MB-231 (Fig. 3C) breast cancer cells in both dose and time dependent manner. The concentrations required to inhibit the growth of $50 \%$ of the cells, i.e. $\mathrm{IC}_{50}$ values were calculated for the different cell lines at the $72 \mathrm{~h}$ time point. The $\mathrm{IC}_{50}$ values were $27 \mu \mathrm{g} / \mathrm{mL}$ for the MCF- 7 aro and $40 \mu \mathrm{g} / \mathrm{mL}$ for the MDA-MB-231 breast cancer cells. It is noteworthy that JFE was less effective at reducing the proliferation of the normal MCF-10A cells (Fig. 3A) with $\mathrm{IC}_{50} \geq 100 \mu \mathrm{g} / \mathrm{mL}$, indicating a specific action on the tumorigenic cell lines. In the current antiproliferative bioassays, we found that JFE was most effective against the estrogen receptor (ER) positive MCF7aro breast cancer cells, compared to the triple negative MDA-MB-231 breast cancer cells. However, further experiments to investigate the mechanisms of anti-proliferative actions of JFE components in breast cancer should be conducted. In addition, whether JFE shows greatest potential against breast cancer compared to other types of cancer cells should be explored. Previous research has shown that a Jamun fruit extract exhibited the most potent cytotoxic activity against MCF7 breast carcinoma cells $\left(\mathrm{IC}_{50}=5.9 \mu \mathrm{g} / \mathrm{mL}\right)$, compared to other cancer cell lines such as the Hela cervix carcinoma cell line, HEPG2 liver carcinoma cell line, H460 lung carcinoma cell line, and U251 brain carcinoma cell line, $\left(\mathrm{IC}_{50}>10 \mu \mathrm{g} / \mathrm{mL}\right)(16)$.

\section{Pro-Apoptotic Effects of Jamun Fruit Extract (JFE)}

The results from the apoptosis study showed no induction of cell death in the MCF-10A line, indicating that JFE is non-toxic to this untransformed cell line as opposed to its pro-apoptotic effect in the two breast cancer cell lines. Although the MCF-7aro cells appeared to be more sensitive to the effects of JFE, the difference in the levels of apoptosis between these two cell lines was not significant.

The limitations of the current study should be taken into context since the JFE levels used in the above cell culture studies may far exceed levels of phenolics and/or their metabolites achievable physiologically. Neverthelesss, our results provide preliminary data as to the ability of JFE to inhibit the growth and induce apoptosis of human breast cancer cell lines in vitro.

The results from the current study warrant further investigation into the potential of $E$. jambolana berries, and its derived food products, as chemopreventive agents against breast cancer. In addition, our future studies will investigate the possible bioactive components of JFE and their mechanisms of action against the proliferation and survival of breast cancer cell lines. 


\section{LITERATURE CITED}

1. American Cancer Society Breast Cancer Facts and Figures for 2007-2008. (available online: http://www.cancer.org/downloads/STT/BCFF-Final.pdf)

2. Chen S, Oh SR, Phung S, Hur G, Ye JJ, Kwok SL, Shrode GE, Belury M, Adams LS, Williams D. Anti-aromatase activity of phytochemicals in white button mushrooms (Agaricus bisporus). Cancer Res 2006;66:12026-12034. [PubMed: 17178902]

3. Kim ND, Mehta R, Yu W, Neeman I, Livney T, Amichay A, Poirier D, Nicholls P, Kirby A, Jiang W, Mansel R, Ramachandran C, Rabi T, Kaplan B, Lansky E. Chemopreventive and adjuvant therapeutic potential of pomegranate (Punica granatum) for human breast cancer. Breast Cancer Res. Treat 2002;71:203-217. [PubMed: 12002340]

4. Veigas JM, Narayan MS, Laxman PM, Neelwarne B. Chemical nature, stability and bioefficacies of anthocyanins from fruit peel of Syzygium cumini Skeels. Food Chem 2007;105:619-627.

5. Sharma B, Viswanath G, Salunke R, Roy P. Effects of flavonoid-rich extract from seeds of Eugenia jambolana (L.) on carbohydrate and lipid metabolism in diabetic mice. Food Chem 2008;110:697705.

6. Helmst0ädter A. Syzygium cumini (L.) Skeels (Myrtaceae) against diabetes-125 years of research. Pharmazie 2008;63:91-101. [PubMed: 18380393]

7. Seeram NP. Berry fruits for cancer prevention: Current status and future prospects. J. Agric. Food Chem 2008;56:630-635. [PubMed: 18211019]

8. Zhang Y, Seeram NP, Lee R, Feng L, Heber D. Isolation and identification of strawberry phenolics with antioxidant and human cancer cell antiproliferative properties. J Agric. Food Chem 2008;56:670675. [PubMed: 18211028]

9. Wang H, Nair MG, Strasburg GM, Booren AM, Gray JI. Antioxidant polyphenols from tart cherries (Prunus cerasus). J Agric Food Chem 1999;47:840-844. [PubMed: 10552377]

10. Giusti, MM.; Wrolstad, RE. Characterization and measurement of anthocyanins by UV-visible spectroscopy. In: Wrolstad, RE.; Acree, TE.; Decker, EA.; Penner, MH.; Reid, DS.; Schwartz, SJ.; Shoemaker, CF.; Smith, D.; Sporns, P., editors. Current Protocols in Food Analytical Chemistry. Vol. 1st ed.. New York: Wiley; 2001. p. F1.2.1-F1.2.13.

11. de Brito ES, de Araújo MC, Alves RE, Carkeet C, Clevidence BA, Novotny JA. Anthocyanins present in selected tropical fruits: acerola, jambolão, jussara, and guajiru. J. Agric Food Chem 2007;55:93899394. [PubMed: 17929888]

12. Wu X, Prior RL. Systematic identification and characterization of anthocyanins by HPLC-ESI-MS/ MS in common foods in the United States: Vegetables, nuts and grains. J. Agric. Food Chem 2005;53:3101-3113. [PubMed: 15826066]

13. Seeram NP, Adams LS, Zhang Y, Lee R, Sand D, Scheuller HS, Heber D. Blackberry, black raspberry, blueberry, cranberry, red raspberry, and strawberry extracts inhibit growth and stimulate apoptosis of human cancer cells in vitro. J Agric. Food Chem 2006;54:9329-9339. [PubMed: 17147415]

14. Jing P, Bomser JA, Schwartz SJ, He J, Magnuson BA, Giusti MM. Structure-function relationships of anthocyanins from various anthocyanin-rich extracts on the inhibition of colon cancer cell growth. J. Agric. Food. Chem 2008;56:9391-9398. [PubMed: 18800807]

15. Jain MC, Seshadri TR. Anthocyanins of Eugenia jambolana fruits. Ind. J. Chem 1975;13:20-23.

16. Nazif NM. The anthocyanin components and cytotoxic activity of Syzygium cumini (L.) fruits growing in Egypt. Nat. Prod. Sci 2007;13:135-139.

\section{ACKNOWLEDGEMENT}

Funding for this project was provided by New Faculty Startup Funds from the College of Pharmacy, University of Rhode Island, to NS. CK was the recipient of a summer undergraduate research fellowship (SURF) award from the RI-INBRE Grant \# P20RR016457 from the National Center for Research Resources (NCRR), a component of the National Institutes of Health (NIH). Mass spectral data were acquired from instrument located in the RI-INBRE core facility at the College of Pharmacy, University of Rhode Island. 


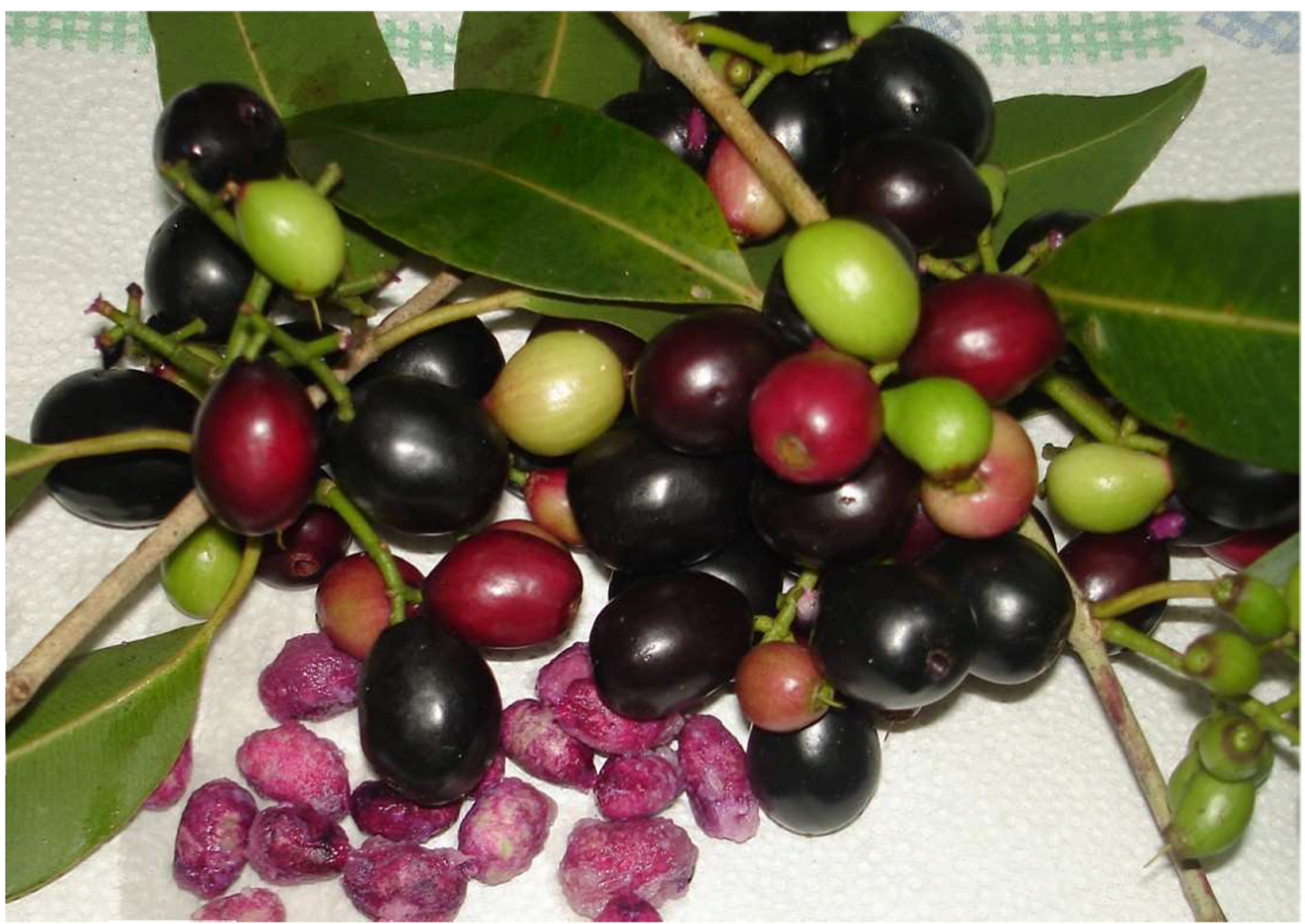

Figure 1.

Eugenia jambolana Lam. (Jamun) berries and seeds (picture by NS from fruits collected in St. Catherine, Jamaica, West Indies). 


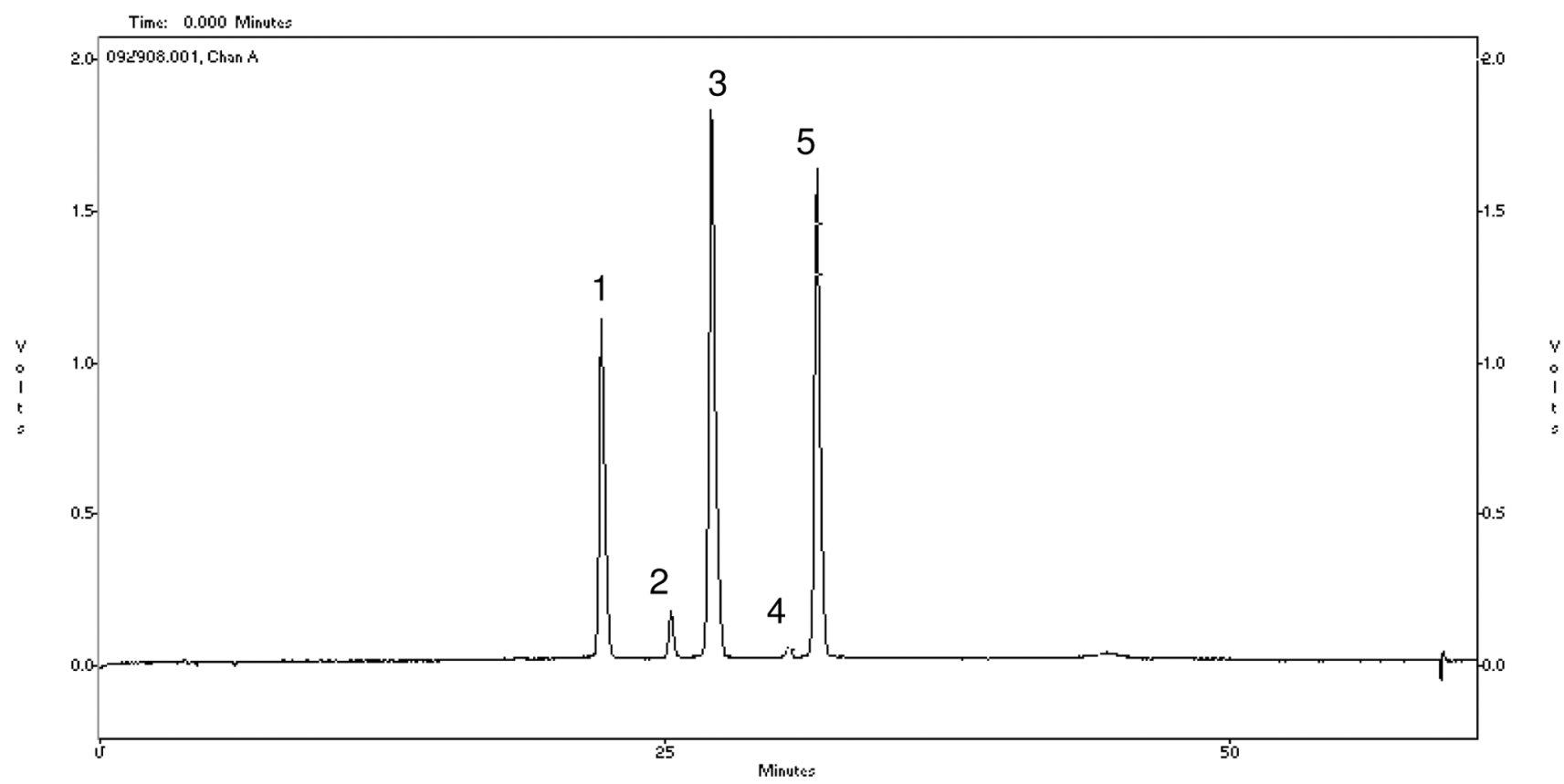



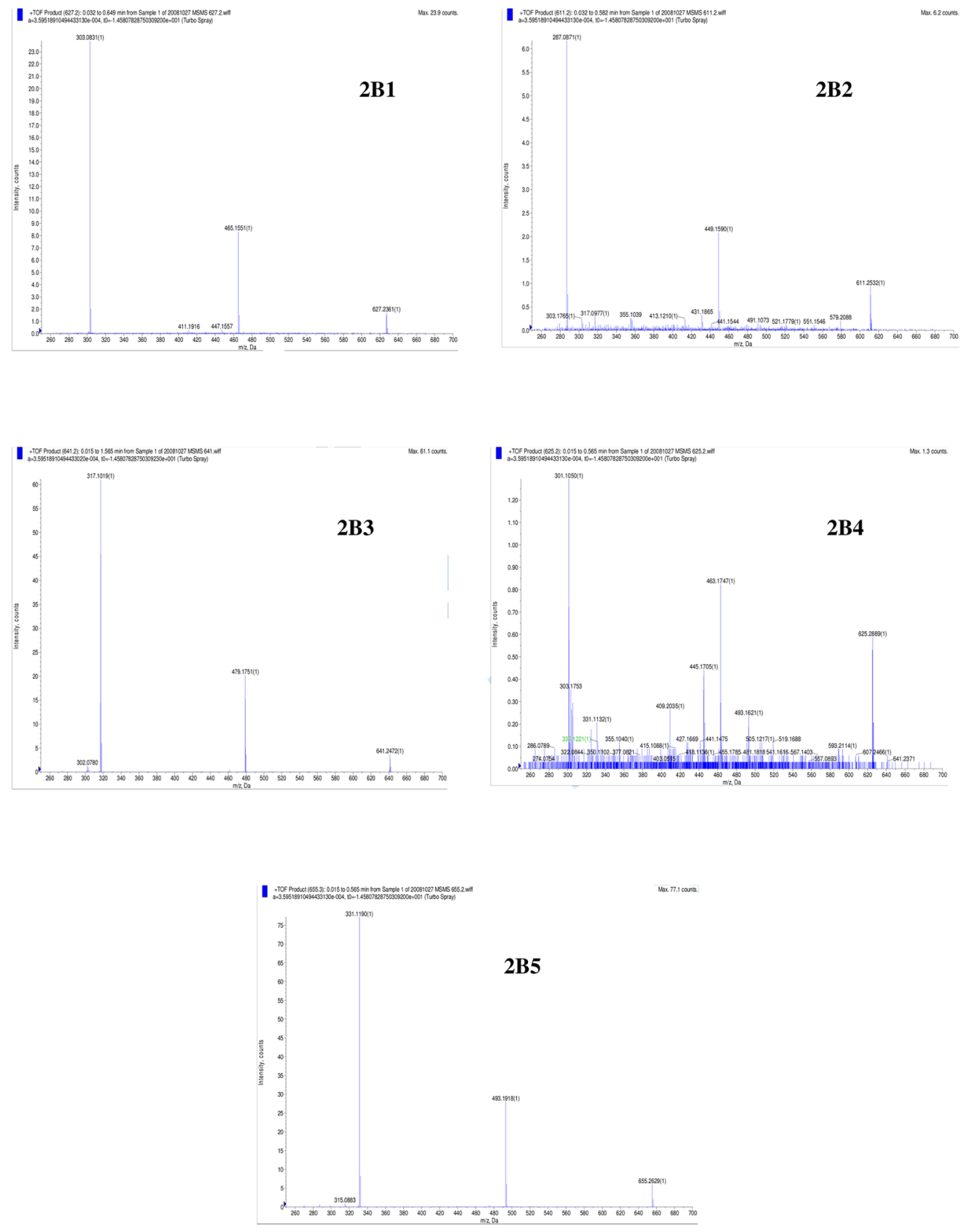

Figure 2A.

HPLC-UV chromatogram of Jamun Fruit Extract (JFE) at $520 \mathrm{~nm}$. Anthocyanins were identified as delphinidin-diglucoside (peak 1, $t_{\mathrm{R}}=22.4 \mathrm{~min}$ ), cyanidin-diglucoside (peak 2 , $\mathrm{t}_{\mathrm{R}}=25.4 \mathrm{~min}$ ), petunidin-diglucoside (peak $3, \mathrm{t}_{\mathrm{R}}=27.2$ ), peonidin-diglucoside (peak $4, \mathrm{t}_{\mathrm{R}}=30.7$ $\mathrm{min}$ ), and malvidin-diglucoside (peak $5, \mathrm{t}_{\mathrm{R}}=31.9 \mathrm{~min}$ ). Figure $2 \mathrm{~B}$ : LC-MS/MS spectrum of the individual anthocyanins present in JFE identified as $\mathrm{m} / \mathrm{z} \mathrm{M}^{+} ; \mathrm{MS} / \mathrm{MS}$ ions as follows $2 \mathrm{~B} 1$ : delphinidin-diglucoside (627;465/303); 2B2: cyanidin-diglucoside $(611 ; 449 / 287) ; 2 \mathrm{~B} 3$ : petunidin-diglucoside $(641 ; 479 / 317), 2 \mathrm{~B} 4$ : peonidin-diglucoside $(625 ; 463 / 301)$, and 2B5: malvidin-diglucoside $(655 ; 493 / 331)$. 

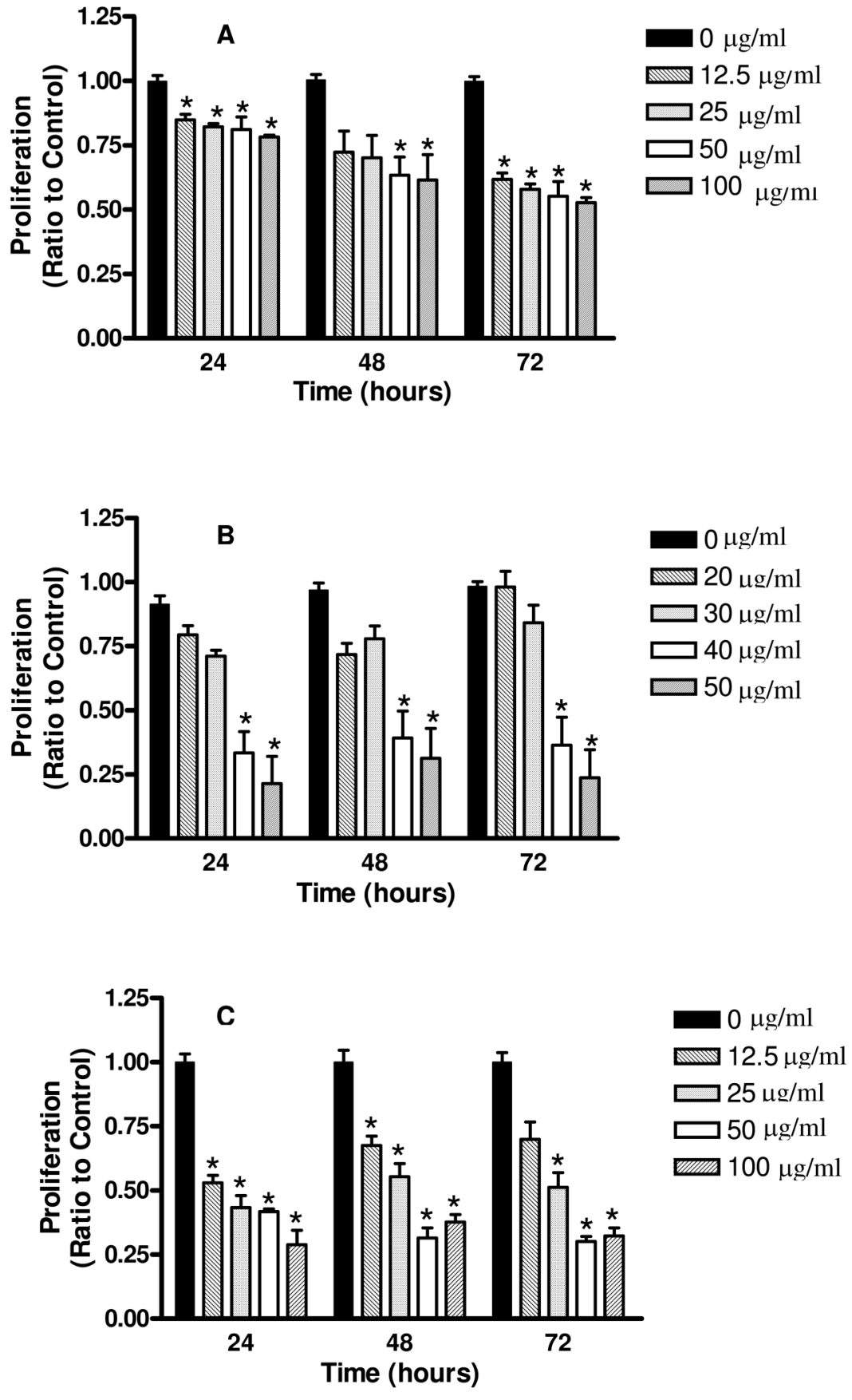

Figure 3.

Antiproliferative activities of JFE against 3A: MCF10A (untransformed/non-tumorigenic) breast cells, 3B: MDA-MB-231 (estrogen independent) breast cancer cells and 3C: MCF7aro (estrogen dependent/aromatase positive) breast cancer cells. Cells were exposed to JFE at concentrations ranging from $0-100 \mu \mathrm{g} / \mathrm{mL}$ for 24,48 or $72 \mathrm{~h}$. Proliferation was measured via the CellTiter-Glo® Luminescent Cell Viability Assay. Data are expressed as percentage of untreated cells, mean $\pm \mathrm{SE}$ and analyzed utilizing One-Way ANOVA followed by Dunnet's Multiple Range test. Asterisk indicates a significant difference compared to untreated controls $(\mathrm{p} \leq 0.01)$. 


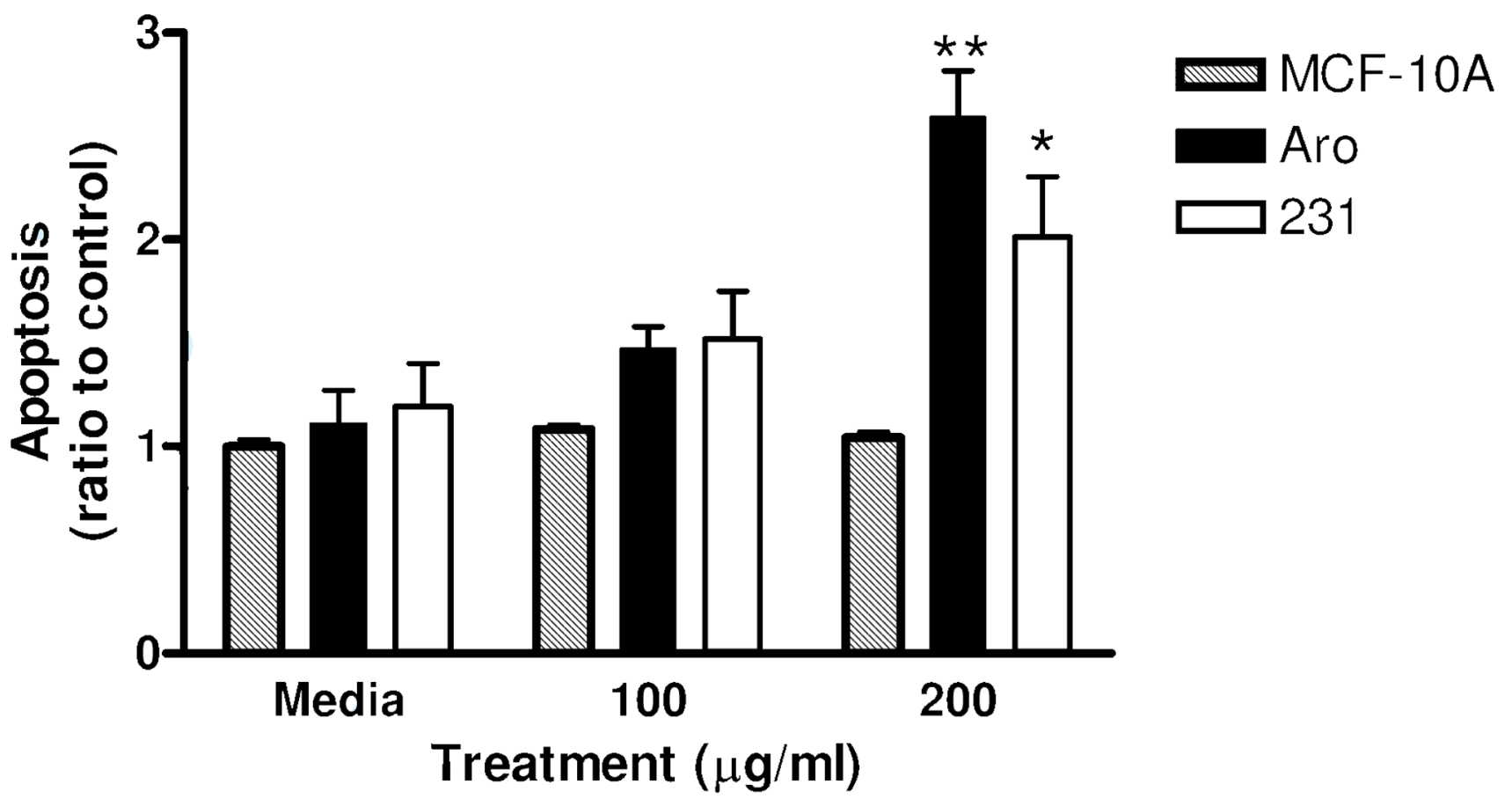

Figure 4.

Apoptosis in : MCF10A (untransformed/non-tumorigenic) breast cells, MCF-7aro (estrogen dependent/aromatase positive) and MDA-MB-231 cells (estrogen independent) breast cancer cells after $48 \mathrm{~h}$ of treatment with JFE. Data are expressed as a ratio of treated samples to media controls \pm SEM and analyzed utilizing One-Way ANOVA followed by Dunnet's Multiple Range test. Single asterisk indicates statistical significance from media controls $\mathrm{p} \leq 0.05$, double asterisk indicates statistical significance $\mathrm{p} \leq 0.01$. 
Table 1

Anthocyanins present in Jamun Fruit Extract (JFE)

\begin{tabular}{|c|c|c|c|c|}
\hline Peak & $\begin{array}{c}\text { HPLC-UV } \\
\text { Retention Time } \\
(\text { min) }\end{array}$ & $\begin{array}{l}{[\mathbf{M}]^{+}} \\
(m / z)\end{array}$ & $\begin{array}{c}\text { MS/MS } \\
(m / z)\end{array}$ & Anthocyanin \\
\hline 1 & 22.4 & 627 & $465 / 303$ & delphinidin-diglucoside \\
\hline 2 & 25.4 & 611 & $449 / 287$ & cyanidin-diglucoside \\
\hline 3 & 27.2 & 641 & $479 / 317$ & petunidin-diglucoside \\
\hline 4 & 30.7 & 625 & $463 / 301$ & peonidin-diglucoside \\
\hline 5 & 31.9 & 655 & $493 / 331$ & malvidin-diglucoside \\
\hline
\end{tabular}

